\title{
Sustainability for Better Living Environment of the Environmental Consumer: Study on International Law and Governance by Focusing the Interest Approach in the Montreal Protocol Through Harmonising the Principle of Transboundary Liability
}

\author{
${ }^{1}$ Muhammad Rizal Razman, ${ }^{2} \mathrm{Jamaluddin}$ Md Jahi, ${ }^{3}$ Kadir Arifin, ${ }^{1}$ Abdul Samad Hadi, \\ ${ }^{3}$ Kadaruddin Aiyub, ${ }^{3}$ Abdul Hadi Harman Shah, ${ }^{1}$ Ahmad Fariz Mohamed, \\ ${ }^{1}$ Shaharudin Idrus, ${ }^{3}$ Azahan Awang and ${ }^{1}$ Nor Fairuz Abu Bakar \\ ${ }^{1}$ Institute for Environment and Development (LESTARI), \\ ${ }^{2}$ Institute of the Malay World and Civilization (ATMA), ${ }^{3}$ School of Social, \\ Development and Environmental Studies, Faculty of Social Science and Humanities, \\ Universiti Kebangsaan Malaysia, 43600 UKM Bangi, Selangor, Malaysia
}

\begin{abstract}
The international environmental law principle on transboundary liability plays an important role in sustainability for better living environment of the environmental consumer. The application of the international environmental law principle on transboundary liability for consumer to enjoy better living environment is largely in respond to the inevitability of every consumer to protect his/her rights on living environment from being polluted. Therefore, this research examines the used of the international environmental law principle on transboundary liability in sustainability for better living environment of the consumer from the international legal scientific approach by identifying actions and cases which deal with environmental protection. This research is also identifying the relation between the international environmental law principle on transboundary liability and Rio Declaration as a means to sustain for better living environment of the consumer. Rio Declaration has laid down essential obligations which contribute the growth and the development of the sustainability for better living environment of the consumer. Finally, the preliminary findings indicate that the influence of interest approach in the international environmental law and governance is rather an important aspect to promote and persuade states around the globe to participate in the Montreal Protocol for the purpose to protect global environment by taking into consideration of the principle of transboundary liability in order to control world emissions of pollution as well as to sustain quality of life for the consumer. These actions are to ensure the sustainability for better living environment.
\end{abstract}

Key words: Consumer, international law and governance, international environmental law principle, the montreal protocol, globe, Malaysia

\section{INTRODUCTION}

The international environmental law principle on transboundary liability plays an important role in sustainability for better living environment of the environmental consumer. The used of the international environmental law principle on transboundary liability for consumer to enjoy better living environment is largely in respond to the inevitability of every consumer to protect his/her rights on living environment from being polluted. Rapid development is the phenomena that have increasingly received international policy makers' attention since, the trend and urbanization pattern have big implication on pollution which includes transboundary pollution. Therefore, in order to attain better living environment, the environment demands careful developmental planning policy. Without a proper planning, the environment will not be able to fulfil its consumers' needs. As the result, this will ruin the environment's consumers' quality of life.

The transboundary liability principle: The Rio Declaration has also laid down essential obligations and responsibilities which contribute to the growth and development of environmental management and law in accordance with the concept of sustainable development and the protection of the environment and for better living environment which include the urban region (Jamaluddin,

Corresponding Author: Muhammad Rizal Razman, Institute for Environment and Development (LESTARI), Universiti Kebangsaan Malaysia, 43600 UKM Bangi, Selangor, Malaysia 
2001; Razman, 2002). One of the essential obligations is on the subject which emphasises that all states in the world are required to ensure that they do not cause environmental harm to other states. This obligation has been mentioned under Principle 2 of the Rio Declaration which states that:

States have in accordance with the charter of the United Nations and the principles of the international law, the sovereign right to exploit their own resources pursuant to their environment and development policies and the responsibility to ensure that activities within their jurisdiction or control do not cause damage to the environment of other States or of areas beyond the limits of national jurisdiction

The above-mentioned obligation is clearly a sign of recognition of the transboundary liability principle (Sands, 1995). The transboundary liability principle is resulted and based on the legal maxim of sic utere tuo, et alienum non laedas which means one should use his own property in such a manner as not to injure of another (Norsulfa, 1997). This transboundary liability principle has been applied in the case of United States and Canada [1941] 3 RIAA 1905, famous as the Trail Smelter case. In this case, the transboundary liability principle was subsequently based upon and further clarified by the Arbitral Tribunal (Hughes, 1992).

The fact of the case: at a place called trail situated in Canada which is about 10 miles from the border between United States of America (USA) and Canada where the Canadian Consolidated Mining and Smelting company had run activities that concerned about smelting zinc and lead. These activities had caused the emission of fumes in the surrounding urban region. These fumes that contained sulfur dioxide had contributed to the damage to the land in the territory of the United States of America. In the year 1931, the United States of America-Canada International Joint Commission which was formed under the Boundary Waters Treaty, 1909 had made decision and required Canada to pay USA for the amount US\$ 350,000 as compensation. After that the above-mentioned smelting company continued to run the operations and activities as usual. USA had made complaints on further damage suffered. Only in the year 1935, the USA and Canada agreed to form an arbitral tribunal on the above-mentioned matter. Later, both countries signed up a convention where both countries referred the above-mentioned dispute to the Arbitral Tribunal (Razman and Jahi, 2002). The Arbitral Tribunal held that:
Under the international law and no state has the right to use or allow to use of her territory in such a manner as to cause injury by fumes in or to the territory of another or the properties or persons therein when the case is of serious consequence and the injury is established by clear and convincing evidence

Therefore, the Arbitral Tribunal gave the decision in favour to the USA where the above-mentioned smelter company was mandatory required to make sure that the company activities shall not cause fumes into the territory of the USA. The above-mentioned decision has established the development of the transboundary liability principle. Based on the above discussion, it is clearly that the transboundary liability principle has promoted two important obligations and responsibilities. These obligations and responsibilities are state responsibility to ensure sustainable development for better living environment and international co-operation and good neighbourliness for better living environment Sands $(1995,2003)$.

State responsibility to ensure sustainable development towards better living environment for consumer: The international law does not allow states in the world to run operations and activities within their jurisdiction without taking care of the environment (Wolf and White, 1995; Razman and Jahi, 2002). This is also for consumer to enjoy better living environment. International law also requires all states around the globe to take adequate and reasonable measures to regulate and control sources of serious environmental pollution and maintain the sustainable development within their jurisdiction in order for better living environment for consumer. This has been supported and reflected in awards and decisions in arbitral tribunals and also in international courts of justice (Birnie and Boyle, 1994; Razman and Jahi, 2002).

In referring to the Trail Smelter case as one of example on heavy development. According to the Trail Smelter case, the Arbitral Tribunal indicated that no state has the right to use or allow to use of her territory in such a manner as to cause injury by fumes in or to the territory of another the properties or persons, present or future therein which clearly shown that it is of all states' responsibility to prevent, reduce and control environmental pollution in that region and maintain the sustainable development within their jurisdiction. In addition in the Corfu channel case support the similar obligation where the International Court of Justice had concluded every state's obligation not to allow knowingly its territory to be used for acts contrary to the rights of 
other states present or future (Harris, 1991; Birnie and Boyle, 1994). Moreover, in the case of Spain and France (1957) 24 I.L.R. 101, well known as Lac Lanoux case where in this case, concerned about the proposed diversion of the international river by France. The Arbitral Tribunal certified that a state has an obligation not to exercise its rights to the extent of ignoring the rights of other state (Harris, 1991). The Arbitral Tribunal further explained:

France is entitled to exercise her rights; she cannot ignore the Spanish interest. Spain is entitled to demand that her rights be respected and that her interests be taken into consideration

International co-operation and good neighbourliness towards better living environment for consumer: The obligation of international co-operation and good neighbourliness has been laid down based on Article 75 of the United Nation Charter in connection with commercial, social and economic subjects which has been defined into the development and application of rules promoting international environmental protection co-operation for the environmental and atmospheric protection (Sands, 1995). Therefore, there are many international environmental treaties, other international acts, international agreements and international declarations which reflect the international co-operation and good neighbourliness for the environmental and better living environment for consumer that derived from the transboundary liability principle (Birnie and Boyle, 1994).

As for the Rio Declaration is concerned, the Declaration has clearly shown an attempt to ensure the international co-operation and good neigbourliness on the matter to protect environment against pollution in order to achieve the sustainable development (Ball and Bell, 1995). The above-mentioned objective is set out in the Principle 27 of the Rio Declaration which provides that:

States and people shall co-operate in good faith and in spirit of partnership in the fulfillment of the principles embodied in this declaration and in further development of international law in the field of sustainable development

According to Sands (1995) this obligation has been accepted in reality of all international agreements on environmental and atmospheric matters of bilateral, regional applications and global instruments. The examples of the bilateral and regional applications: (a) Article 12 (2) London Convention 1933 and (b) Article 2
(1) Alpine Convention 1991 (Razman and Jahi, 2002). On the other hand as for the global instruments' examples as follows: (a) Article 2 (2) Vienna Convention 1985 and Article 5 Biodiversity Convention 1992 (Razman and Jahi, 2002).

The obligation may be in the manner of specific provisions under a treaty such as Article 4 (1) (e) Climate Change Convention 1992 and Article 14 Lome Convention 1989 or in the manner of general provisions which in connection with the implementation of the treaty's objectives such as Article XVI (1) African Conservation Convention 1968 and Article 5 Biodiversity Convention 1992 (Razman and Jahi, 2002). In the dispute over the Gabcikovo Dam, for an example, the proposed diversion of the Danube river where the dispute was between Hungary and Slovakia. In this dispute, clearly, the obligation of international co-operation and good neighbourliness has been the central issue (Sands, 1995; Razman and Jahi, 2002). Here, Hungary laid down claimed against Slovakia on the ground that Slovakia implement of principles affecting transboundary resources which inconsistent with the obligation of international cooperation and good neighbourliness (Sands, 1995; Razman and Jahi, 2002).

Therefore, from the above-mentioned dispute clearly indicated that the states practice to apply this obligation of international co-operation and good neighbourliness on the matter to protect environment against environmental harm and to maintain sustainable development. This means that the principle also apply to the issues on matter of the protection on the atmosphere.

Transboundary pollution and the impact to consumer: Basically, there were two major disasters in the middle 1980 's which involved transboundary pollution in urban region and the violation on the concept of sustainable development. One incidence happened in Soviet Union and the other occurred in Switzerland. The first disaster happened in Chernobyl, Soviet Union where a nuclear reactor exploded on 26th April 1986. A huge amount of radioactive emitted to the atmosphere, especially European atmosphere. A number of people outside Soviet Union were affected by the disaster. Soviet Union authority informed public only after 15 days after the incident took place. At the time of the notification made by Soviet Union authority, number of people in the European Continent had already affected. Unfortunately, there was no action taken against the Soviet Union for the present and future safety of the mankind. This disaster is known as Chernobyl Explosion (Norsulfa, 1997; 
Razman and Jahi, 2002). This disaster clearly shown that the absence of the compliance with the concept of sustainable development which emphasises that all development that meets the needs of the present generation without compromising the ability of the future generations to meet their own needs. The second incidence and disaster happened when a company's warehouse that was Sandoz Corporation's warehouse in Schweizerhale, Switzerland caught fire on 1st November 1986. The chemical from the said warehouse had polluted Rhine river by seeping through the Sandoz Corporation's sewer system.

This had caused the formation of toxic which harmful to the living things and creatures in the Rhine river. Switzerland authority only informed the neighbouring countries, $24 \mathrm{~h}$ after the disaster. Immediately, after the notification, France government shut down all the water supply along the said river. As the result of this disaster, Sandoz Corporation had paid a lot of claims privately. Nevertheless none of the neighbouring countries brought the action against Switzerland for the present and future safety of the mankind. This incidence and disaster is known as Sandoz Spill (Norsulfa, 1997; Razman and Jahi, 2002). The second disaster also highlighted the violation on the concept of sustainable development which failed to ensure the safety of present and also future generations as well as consumer.

Post Sandoz Spill and Chernobyl Explosion from international law and governance perspectives: Based on the above discussion, both countries, Switzerland and Soviet Union free from the above-mentioned liability. There was no action has been taken against these two countries in the year which the said incidents and disasters occurred. This due to insufficiently articulated any international obligations concerning to state obligation in the situation of transboundary environmental disasters. These two disasters Sandoz Spill and Chernobyl Explosion have caused the growth of the international community awareness on the importance of the principle of transboundary liability on the transboundary environmental disasters.

Therefore, there are two famous international legal documents that try to address the above-mentioned matter.

According to the Article 18 of the Rio Declaration, 1992 stated that states are required to take immediately action to notify other states of any natural disasters or other emergencies that are likely to produce sudden harmful effects on the environment of the other states.
As for the Article 19 of the Rio Declaration, 1992 mentioned states shall provide prior and timely notification and relevant information to potentially affected states on activities that may have significant adverse transboundary environmental effect and shall consult with those states at early state and in good faith (Sands, 1995; Razman and Jahi, 2002).

In the Article 27 of the International Law Commission's Draft Articles on the Non-Navigational Uses of International Watercourses Law, 1994 laid down states are required to mitigate or prevent conditions of any disasters which might affect any other state. As for the Article 28 of the International Law Commission's Draft Articles on the Non-Navigational Uses of International Watercourses Law, 1994 required states to notify other states of an emergency originating within its jurisdiction, to mitigate, prevent and eliminate any harmful effects of the emergency and to develop contingency plans for responsibility to the emergency (Norsulfa, 1997; Razman and Jahi, 2002). The International Law Commission's Draft Articles on the Non-Navigational Uses of International Watercourses Law, 1994 is the complementing to the Rio Declaration, 1992 (Norsulfa, 1997). These two international legal documents expressly laid down the obligations of all states throughout the globe on transboundary environmental harms and to ensure to the safety of the present and future generations. This clearly shown the growth and the development of the principle of transboundary liability and environmental protection and the concept of sustainable development.

\section{The montreal protocol and interest approach in adopting on the principle of transboundary liability towards better living environment for consumer}

The montreal protocol: The Montreal Protocol has been enacted for the protection of the ozone layer by taking precautionary measures to control world emissions of substances that deplete the ozone (Conservation and Environmental Management Division, MOSTE, 2004) by promoting the principle of transboundary liability. Awareness on the existence of ozone layer, i.e., $\mathrm{O}_{3}$ at the stratosphere and threat of Chlorofluorocarbons (CFCs) as ozone depletion substance has increased radically at the early years of 1970s (Seaver, 1997; Breitmeier, 1997; Breitmeier et al., 2006). Moreover, both scientists and policy makers had made a lot of initiatives in order to capture global attention about the threat of CFCs towards the ozone layer. As a result, at the middle 1980s, ozone layer problems became global concerns due to transboundary movement of the said chemicals 
(Breitmeier, 1997; Breitmeier et al., 2006). Starting from this point, the global concerns became the catalyst for the international environmental cooperation and gave birth to the Montreal Protocol in order to acheive sustainable development (Bjorn, 2007).

Objectives of this study: This study embarks on the following objectives:

- To identify and analyse the themes and sub-themes that relate to the influence of the interest approach that promotes the principle of transboundary liability in the early stage of negotiations that build up the international environmental cooperation in the Montreal Protocol

- To explain the influence of the interest approach that promotes the principle of transboundary liability in the early stage of negotiations that build up the international environmental cooperation in the Montreal Protocol

\section{MATERIALS AND METHODS}

This study applied a qualitative set up. In line with the qualitative approach, the Montreal Protocol has been employed as a case study in this study. Hence, this study has analysed some of the relevant meeting documents of the Montreal Protocol.

Documents selection: This study is intimately linked to the international environmental cooperation in the Montreal Protocol, the influence of interest approach and also the response of the member states. Therefore, the following documents have being selected as the main documents of this study. The documents are as follow:

Document 1: Meeting reports of the First Session-Ad Hoc Working Group of Legal and Technical Experts for the Preparation of a Protocol on Chlorofluorocarbons to Vienna Convention for the Protection of the Ozone Layer' on 1-5 December 1986 at Geneva, Switzerland.

Document 2: Meeting reports of the Second Session-Ad Hoc Working Group of Legal and Technical Experts for the Preparation of a Protocol on Chlorofluorocarbons to Vienna Convention for the protection of the ozone layer on 23-27 February1987 at Vienna, Austria.

Document 3: Meeting reports of the First Meeting-Ad Hoc Working Group of Legal and Technical Experts for the Harmonization of data on production, imports and exports of substances that deplete the ozone layer on 9-11 March, 1988 at Nairobi, Kenya.

Document 4: Meeting reports of the Second Meeting-Ad Hoc Working Group of Legal and Technical Experts for the Harmonization of data on production, imports and exports of substances that deplete the ozone layer on 24-26 October, 1988 at The Hague, Netherlands.

Document 5: Meeting reports-Meeting of Parties (Montreal Protocol) on 2-5 May, 1989 at Helsinki, Finland.

Document 6: Meeting reports of the First Session-OpenEnded Working Group of The Parties' (Montreal Protocol) on 21-25 August, 1989 at Nairobi, Kenya.

The documents have been selected on the basis that those documents represent the early stage of negotiations of the Montreal Protocol. The first two documents represent negotiations in the making of the Montreal Protocol itself whereas the last four documents represent negotiations to persuade and attract more developing nations to join as members of the Montreal Protocol.

Documents analysis: All the documents were analysed by using Nvivo 2 software. By using Nvivo 2 software, the researchers have built up and tested the coding schemes. This action was necessary in order to determine the reliability. According to Maxwell there are a few necessary steps in analysing documents by using the software. All the documents are identified and selected for the purpose of fulfilling the study objectives the above-mentioned documents. These documents are numbered 1-6. Later, these documents are scanned in order to transform them into transcripts that can be analysed by computer software (Nvivo 2).

By using computer software (Nvivo 2), the researchers identified themes and sub-themes based on the above-mentioned selected documents which are in line with the study objectives. Following that the researchers are required to determine the reliability of the coding schemes during the process of identifying themes and sub-themes by using computer software (Nvivo 2). This determination of reliability is based on the reliability index of Cohen Kappa. This process is required to be repeated many times until the coding schemes manage to obtain the highest level of the reliability. Finally, these themes and sub-themes are built up by displaying these results in the form of a model. This process of documents analysis has been laid down in Fig. 1. 


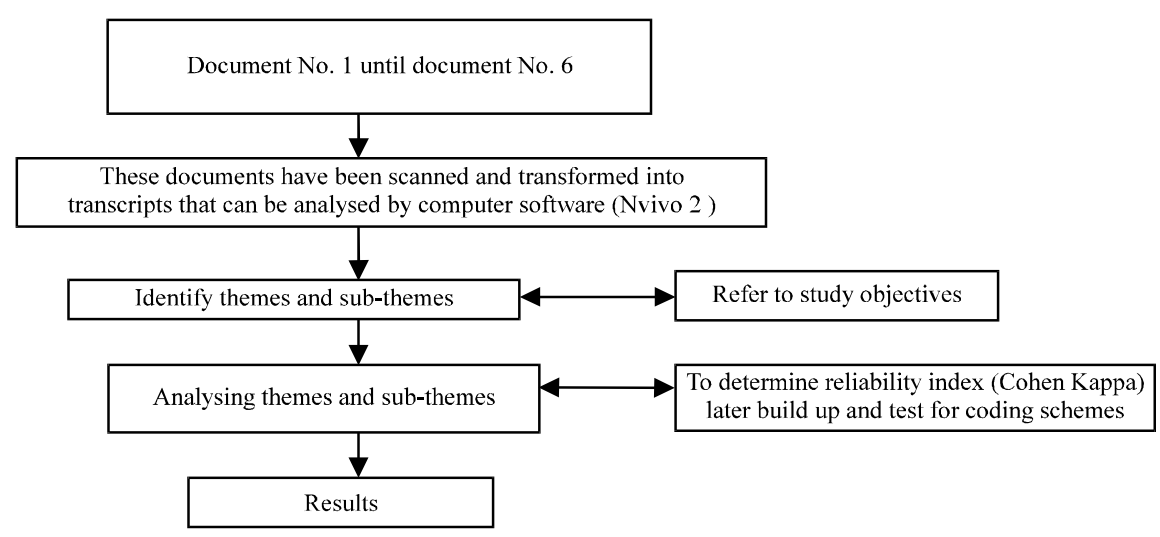

Fig. 1: Documents analysis process flow chart

\section{RESULTS AND DISCUSSION}

Based on the documents analysis on the influence of interest approach that promotes the principle of transboundary liability in the early negotiations of the Montreal Protocol, two main themes and eight sub-themes have been identified (Table 1). The themes are costs and benefits while the sub-themes are implementation costs, market competitiveness, international trade conflict, increasing prices, flexibility, justice, incentives (technical and financial assistance) and costeffectiveness.

Costs: When referring to the influence of interest approach in the negotiation of the Montreal Protocol, it is clear that the costs have played essential roles on this matter. This has been highlighted in document no. 2 indicates the subject matter:

Another expert drew attention to the problems faced by small countries which might suffer increased costs or reduced availability of chemicals if producing nations restricted exports in favour of continued domestic consumption under regulatory measures [Para 177, Document No. 2]

Implementation costs: This study has shown that implementation costs were also being considered as factors that influence states to participate in international environmental cooperation of the Montreal Protocol. This has been highlighted in document No. 6:

Incremental costs that might be covered by the international financial mechanism [Para 103, Document No. 6]
Table 1: Themes and sub-themes of documents analysis of the interest approach that promotes the principle of transboundary liability in the montreal protocol-better living environment for consumer

\begin{tabular}{ll} 
Costs & Sub themes \\
\hline Implementation costs, market competitiveness,
\end{tabular} intemational trade conflict and increasing prices Benefits Flexibility, justice, incentives (technical and financial assistance) and cost-effectiveness

Market competitiveness: Beside the implementation costs which has been highlighted above, market competitiveness has also been mentioned for consideration in order to influence the negotiation of the the Montreal Protocol. This has been highlighted in document No. 1 indicating the said matter:

The delegates warned that a freeze at the 1986 production level as contained in one draft protocol before the group would lead to a production monopoly for current producers [Para 116, Document No. 1]

International trade conflict: In the early negotiation of the Montreal Protocol, all of the states around the globe were looking forward that controlling trade measures in the Montreal Protocol should be consistent with the international trade laws in order to avoid international trade conflict that might caused international trade problems. This has been highlighted in document No. 2 that indicates the subject matter:

The sub-group on trade issues considered the compatibility of measures for controlling trade between parties to the Protocol and trade between parties and non-parties with the rules of international trade, especially the GATT [Para 301, Document No. 2] 
Increasing prices: In addition to the discussion under the main theme costs which are based on document No. 6 , member states during the negotiation always ensure that the Montreal Protocol must take into consideration on the incresing prices due to the involvement of incresing costs in implementing the Montreal Protocol:

$\mathrm{He}$ outlined the elements of the cost as follows; a) the costs of using or manufacturing high price $\mathrm{CFC}$ substitutes; b) the costs of amortization; c) the cost of adjustments in industries using CFCs and halons as inputs and the higher costs of importation of equipment and goods using the substitutes [Para 91, Document No. 6]

Benefits: The second main theme that influence the negotiation of the Montreal Protocol from the interest approach perspective is also clear that the benefits have played essential roles on this matter. This has been highlighted in document No. 6 which indicates the subject matter:

$\mathrm{He}$ first identified the needs of developing countries; their reticence to ratify the Montreal Protocol was due to lack of the resources necessary to met its requirements without serious disruption of their development efforts what they needed was concessional funding and outright grants additional to existing aid programmes [Para 18, Document No.6]

Flexibility: These benefits are also including the aspect of flexibility. This aspect of flexibility really helps to influence states around the globe to join in and ratify the Montreal Protocol.

During the negotiation of the Montreal Protocol many developing states have requested for the flexibility in implementing the Montreal Protocol. This has been highlighted in document No. 2 which indicates the said matter:

Special clauses must be drafted for the developing countries that take into account their particular situation and that at a minimum, permit them to continue their production and emission at current levels, since these countries are not in a position to replace these substances in addition to which they are experiencing a very difficult economic situation [Para 96, Document No. 2]

Justice: This study has shown in document No. 1 that justice also bring benefits to states around the world during the negotiation of the Montreal Protocol because with the application of the principle of fairness in the Montreal Protocol, the Montreal Protocol will become international law that would be accepted through out the world:

He said however, in doing so it was important to apply the principle of fairness so that the regulations would be acceptable to all [Para 85 Document No. 1]

Incentives (technical and financial assistance): Incentives on technical and financial assistance bring benefits to member states, especially to the developing nations in accepting the Montreal Protocol as one of the international environmental laws. This has been highlighted in document No. 6 that indicates the subject matter:

Two main purposes for financial or other support: first, compensation for the incremental costs of transition to substitutes of the ozone depleting substances and second, support which would serve as an incentive to ensure adherence to the Protocol [Para 178, Document No. (6)]

Cost-effectiveness: Cost-effectiveness which bring benefits to member states by sharing the burden of costs relative to the regulatory process among governments. This has been highlighted in document No. 2:

Mr. Mansfield enumerated some of these issues; on the substances that should be regulated on the levels of limitations to be chosen; on the cost-effectiveness of regulations and on how the burden of costs relative to the regulatory process would be shared among governments [Para 32, Document No. 2]

\section{CONCLUSION}

The transboundary liability principle imposed liability towards a country for the adverse activities and operations within the said state jurisdiction that caused environmental harm to the other state. On regards with this transboundary liability principle and environmental protection towards better living environment for consumer however, this principle is still evolving and required of further development and growth.

The opportunity to enhance the growth of this transboundary liability principle and the environmental protection towards better living environment for consumer, through state practice following the transboundary disaster Chernobyl Explosion was lost due 
to the decision by the injured countries not to take international legal action for causing environmental pollution and violation on the concept of sustainable development, even though the injured countries have their right to do so (Sands, 1995; Razman and Jahi, 2002). The support made by the countries around the world on the International Law Commission's Draft Articles on the Non-Navigational Uses of International Watercourses Law, 1994 and the Rio Declaration, 1992 are clearly the acceptance and the growth of this principle of transboundary liability in protecting consumer, especially towards better living environment (Sands, 1995; Razman and Jahi, 2002).

The study suggests that interest approach that promotes the principle of transboundary liability is rather an important feature to encourage and influence states around the globe to participate in the Montreal Protocol. After a series of negotiations, most of the negotiating countries felt that the Montreal Protocol would be able to supply the market for substitutes of CFCs and would not be exaggerated upsetting the global cost-effectively and to ensure the principle of transboundary liability will not be infringed. This study also suggests that the global economics and equity matters were also discussed in the negotiations of the Montreal Protocol.

The developing states have tried to seek justice by promoting the principle of transboundary liability. Based on these two principles, the states managed to obtain flexibility in implementing the Montreal Protocol through the global forum of UNEP. Under this umbrella of the global forum of UNEP the Montreal Protocol has managed to minimise the conflict between the global environmental issues, the global economics and equity matters. Moreover, the developing states which are regarded as Article 5 states in the Montreal Protocol have also been given incentives on technical and financial assistance through Multilateral Fund in order to help them in implementing the Montreal Protocol to avoid the infringement of the principle of transboundary liability for better living environment for consumer.

\section{ACKNOWLEDGEMENT}

This study was conducted by using the research funding of the UKM-GGPM-PLW-037-2010 project.

\section{REFERENCES}

Ball, S. and S. Bell, 1995. Environmental Law. Blackstone Press Ltd., London.

Birnie, P.W. and A.E. Boyle, 1994. International Law and the Environment. Clarendon Press, Oxford.

Bjorn, L.O., 2007. Stratospheric ozone, ultraviolet radiation and cryptogams. Biol. Conserv., 135: 326-333.
Breitmeier, H., 1997. International Organizations and the Creation of Environmental Regimes. In: Rights, Rules, Resources in World Affairs. Global Governance: Drawing Insights from Environmental Experience, Young, O.R. (Ed.). 1st Edn., MT Press, Cambridge, Massachusetts, ISBN: 10-0-262-74020-6, pp: 87-114.

Breitmeier, H., O.R. Young and M. Zurn, 2006. Analyzing International Environmental Regimes. From Case Study to Database. 1st Edn., MП Press, Cambridge, MA., ISBN: 10-0-262-52461-9.

Conservation and Environmental Management Division, MOSTE, 2004. Multilateral environmental agreements with MOSTE as national focal point. Putrajaya: Ministry of Science, Technology and Environment.

Harris, D.J., 1991. Cases and Materials on International Law. Sweet and Maxwell, London.

Hughes, D., 1992. Environmental Law. Butterworth and Co. Publishers Ltd., London.

Jamaluddin, J., 2001. Pengurusan alam sekitar di Malaysia: Dari Stockholm ke Rio de Janerio dan seterusnya. Syarahan Perdana Universiti Kebangsaan Malaysia, 16 Februari, Penerbit Kebangsaan Malaysia University, Bangi.

Norsulfa, M.S.S., 1997. The right to clean air: Is there legal liability for transboundary pollution? Bar Council Infoline, 9: 3-7.

Razman, M.R.B. and J.M. Jahi, 2002. The Principle of Transboundary Liability and Environmental Protection: International Legal Perspectives. In: Bangi: Environmental Management Programme, Jahi, J.M., M.J.M. Nor, K. Sopian, I. Sahid and A.H.H. Shah (Eds.). Centre for Graduate Studies, Universiti Kebangsaan Malaysia, pp: 155-161.

Razman, M.R.B., 2002. Pemakaian Undang-Undang Kecuaian di Dalam Menangani Pencemaran Alam Sekitar di Malaysia. In: Isu-Isu Persekitaran di Malaysia: Bangi: Program Pengurusan Persekitaran, Jahi, J.M., M.J.M. Nor, K. Arifin and M.R. Razman (Eds.). Pusat Pengajian Siswazah, Universiti Kebangsaan Malaysia, pp: 61-76.

Sands, P., 1995. Principles of International Environmental Law I: Frameworks, Standards and Implementation. Manchester University Press, Manchester.

Sands, P., 2003. Principles of International Environmental Law. Cambridge University Press, Cambridge.

Seaver, B., 1997. Stratospheric ozone protection: IR Theory and the Montreal Protocol on substances that deplete the ozone layer. Environ. Politics, 6: 31-67.

Wolf, S. and A. White, 1995. Environmental law. Cavendish Publishing Limited, London. 